\title{
"Acting in Accordance with the Ordinary Legislative Procedure...": Metadiscourse in EU Regulations on Immigration
}

\author{
Michela Giordano ${ }^{1} \&$ Antonio Piga ${ }^{1}$ \\ ${ }^{1}$ Department of Humanities, Languages and Heritage, University of Cagliari, Italy \\ Correspondence: Michela Giordano, Department of Humanities, Languages and Heritage-Via Is Mirrionis, 1, \\ 09100 Cagliari, Italy. E-mail: mgiordano@unica.it
}

Received: March 18, 2021

Accepted: April 20, $2021 \quad$ Online Published: May 8, 2021

doi:10.5539/ijel.v11n3p49

URL: https://doi.org/10.5539/ijel.v11n3p49

\begin{abstract}
The ongoing Pan-European integration process has profoundly influenced the nature of European law and its development, demanding a review of "the ways of how language [...] is materialized" (Gibová, 2009, p. 192). EU multilingualism is thus becoming an intricate concept since "EU translation is $[\ldots]$ becoming the language of Europe" (Gibová, 2009, p. 192) encompassing a supranational view of the world conveyed in EU-wide legislation. Very much in line with this assumption, and taking into account the teaching experience in Specialised Translation Masters' courses training would-be professional translators, this study examines a corpus of European Parliament Regulations on immigration. In order to understand whether dissimilarities and/or congruencies occur between the EU working language, i.e., English, and the Italian versions, the metadiscourse framework by Hyland (2005), comprising both interactive and interactional features, is used as the point of departure for the analysis of parallel texts. The Regulations produced by EU institutions and conveyed and transmitted both in English as a "procedural language" (Wagner, Bech, \& Martínez, 2012) as well as in Italian have been scrutinized both quantitatively and qualitatively, in order to draw precious pedagogical implications for translation studies and professional practice for future qualified and trained translators.
\end{abstract}

Keywords: metadiscourse, parallel corpora, translation, Systemic Functional Linguistics, genre analysis, corpus analysis

\section{Introduction}

This study deals with metadiscourse in EU regulations on immigration and issues related to it. Immigration is one of the authors' regular and ongoing research topics and it is currently being looked at from different perspectives and through the examination of different texts (i.e., parliamentary debates, regulations and directives, to name just a few). This particular research takes into account certain linguistic features which are fundamental to the Specialised Translation Masters' courses at the University of Cagliari, Italy. As a matter of fact, we firmly believe that in order to adequately train future translators at a university level - both in terms of the scientific methodology to be acquired and the professional orientation and attitudes to be developed, Specialised Translation didactics must take into account various linguistic theories and methodologies with the purpose of obtaining a wide-ranging and comprehensive understanding and awareness of text typology, genre, register and style. A typical translation lesson in the Masters courses cited above is generally organised around three main stages which are concurrent and complementary to the actual translation work: corpus analysis, genre analysis and linguistic analysis through Systemic Functional Linguistics.

These three methodologies are applied to parallel texts (i.e., source texts and their translations), taken in this case from the Multilingual/Bilingual Display of the EUR Lex website, which provides aligned texts proven to be highly useful for class work. Parallel corpora are invaluable resources of information for searching and discovering typical and well-established translation equivalents of certain terms and expressions, especially when dealing with specialised discourse. Specialised translation undoubtedly requires a sound knowledge of the two languages, source language (SL) and target language (TL), an in-depth understanding of the subject field as well as sufficient acquaintance and familiarity with legal concepts and terms in both the SL and the TL. All these elements are fundamental in order to preserve and adjust the draft translation to the style and register that are appropriate to a specific text type and genre and to the particular linguistic and professional community under scrutiny. 
The classroom experiences in the Cagliari University Translation Masters courses have shown that the use of small and ad hoc parallel corpora can raise students' understanding and awareness of professional translator strategies, produce naturally-sounding translated texts and even guide the students in the building of small or relatively small translation corpora which itself provides a valuable and precious learning activity for professional development (Bernardini \& Castagnoli, 2008). The qualitative linguistic analysis which is carried out together with a quantitative analysis, helps students to recognise certain stylistic and pragmatic traits and to identify and classify register and genre conventions typical of the text under scrutiny. This is what some authors call quantitative-driven qualitativeness, in the sense that it is necessary to combine quantitative methods with qualitative ones (Biel, 2010, p. 6). In this way, an all-encompassing approach stresses both the university educational process and students' professional training practice. This study is therefore an example of the linguistic analysis carried out in the context of translation teaching courses and consequently is of interest both for university instructors and for students who will be potential professionals in the field of institutional translation at a European or global level.

To begin with, EU regulations are explored as a legal genre with specific features. Fig. 1 below represents all the types of documents and instruments issued by the European Parliament and Council. They include regulations, directives, decisions, recommendations and opinions, as explained by Borchardt in The ABC of EU Law (2018). In particular, the present study deals with regulations which are the most binding documents among the ones selected. They belong to Secondary Law of the EU (Primary Law are the Treaties). They are legal acts of the EU, in the sense that they are equivalent to Acts of Parliament. They are directly applicable and enforceable in all Members States simultaneously and, unlike Directives, they do not need to be transposed into national law by means of implementing measures. They override all national laws dealing with the same subject. What they state is law and this is particularly important for our linguistic analysis of translations. Borchardt's work provides an "initial insight into the structure of the Union and the supporting pillars of the European legal order" (https://op.europa.eu/en/publication-detail/).

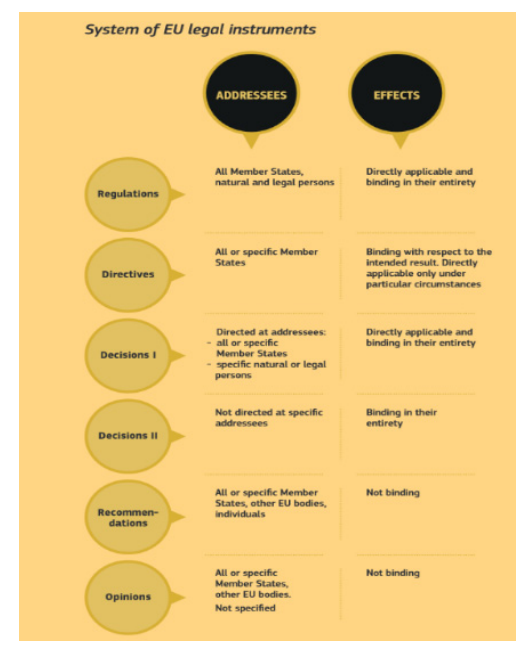

Figure 1. System of EU legal instruments (The ABC of EU Law, 2018, p. 99)

There are a series of basic principles to take into account when studying or dealing with EU translations. First of all, the concept of institutional multilingualism (Wagner, Bech, \& Martínez, 2012, p. 1) means that all the 23 languages of the EU have equal status. The EU has official languages, working languages and procedural languages (these are English, French and German) or core languages (Gibová, 2009, p. 193) but the institutions produce legislation that is directly applicable to all citizens in all the Member States, therefore this has to be available and accessible in a language all citizens can understand. Specifically, Council Regulation n. 1, determining the languages to be used by the EU, does not mention or indeed refer specifically to translations (Wagner et al., 2012, p. 7): it talks instead about 23 language versions and about authenticity where the word authentic stands for legally valid (Wagner et al., 2012, p. 5). It is useful to highlight that despite the existence of more than one procedural language, "given the increasing popularity of English, translators tend to choose the English versions as original source texts (Felici, 2010, p. 103).

This might be interpreted as a sort of conspiracy against professional translators but this is not the case because, 
as a matter of fact, translators and interpreters make up a large proportion of EU institutional staff: "[t]ranslation is needed at all the many stages in the preparation of EU legislation" (Wagner et al., 2012, p. 3). Nonetheless, "just as the writers of the documents often remain anonymous, the translators are necessarily unidentified" and "[t]o the outside world, EU translators are, and probably will remain, relatively invisible" (Koskinen, 2001, p. 298).

\section{Literature Review}

The theoretical framework is based on metadiscourse resources (Hyland, 2005) and Systemic Functional Linguistics (Halliday, 1985; Halliday \& Matthiessen, 2004; Martin, 1991).

Hyland (2005) developed a taxonomy in which he distinguished between interactive features, which fulfil the writer's management of propositional information in order to guide readers through a text, and interactional features, which are used by the writer to comment on content material. As can be seen in Table 1 below, the scholar listed five sub-categories as interactive resources (transition markers, frame markers, endophoric markers, evidentials, and code glosses), and five sub-categories as interactional resources (hedges, boosters, attitude markers, self-mentions and engagement markers).

Table 1. Hyland's interpersonal model of metadiscourse (2005, p. 49)

\begin{tabular}{lll}
\hline Category & Function & Examples \\
\hline Interactive & Help to guide the reader through the text & Resources \\
Transitions & express relations between main clauses & in addition; but; thus; and \\
Frame markers & refer to discourse acts, sequences or stages & finally; to conclude; my purpose is \\
Endophoric markers & refer to information in other parts of the text & noted above; see Figure; in section 2 \\
Evidentials & refer to information from other texts & according to X; Z states \\
Code glosses & elaborate propositional meanings & namely; e.g.; such as; in other words \\
Interactional & Involve the reader in the text & Resources \\
Hedges & withold commitment and open dialogue & might; perhaps; possible; about \\
Boosters & emphasize certainty or close dialogue & in fact; definitely; it is clear that \\
Attitude markers & express writer's attitude to proposition & unfortunately; I agree; surprisingly \\
Self-mentions & explicit reference to author(s) & I; we; my; me; our \\
Engagement markers & explicitly build relationship with reader & consider; note; you can see that \\
\hline
\end{tabular}

Within this broad approach, Hyland defined metadiscourse as the writer's linguistic choices in organizing a discourse and to show the writer's own stance in relation to the content matter and the potential reader. The writer's choice of cohesive and interpersonal features is therefore intended to help relate a text to its context of situation by assisting readers to connect to it, and interpret it based on the values of a specific discourse community. In the light of this perspective, metadiscourse is context dependent, and its characteristics differ across genres and languages; in other words, metadiscoursal functions may be performed in different ways, and single items may perform more than one metadiscoursal function in the same or in different contexts. Accordingly, in emphasizing the concept that metadiscourse is a pragmatic category, Hyland recommends examining metadiscourse features in their contexts to ensure they are actually performing metadiscourse functions, yet does not reject corpus-based investigation.

In combination with Hyland's metadiscourse features, this study takes into consideration Systemic Functional Linguistics. According to Halliday (1985), Martin (1991), Halliday and Matthiessen (2004), a clause is a unit in which meanings of three different kinds are combined, each expressing one kind of semantic organization: Field: Clause as representation; Mode: Clause as message; Tenor: Clause as exchange.

The topic of EU translation, their investigation through parallel corpora and their employment in translator education and training has been widely explored by scholars belonging to diverse backgrounds, such as Scarpa (2006), Bernardini and Castagnoli (2008), Felici (2010), Biel (2009), and Pearson (2014).

Additionally, useful insight for this study was gained from studies that apply corpus linguistics and quantitative analysis to texts dealing with immigration and some of the issues related to this topic, such as Baker and McEnery (2005), Manca (2015), Grego and Vicentini (2015), Al Fajri (2017) and Giordano and Piga (2020), along with seminal studies on genre analysis such as Bhatia (1993) and Swales (1990).

\section{Data and Methodology}

The corpus for our study comprised three Regulations on immigration (2016, 2018 and 2019) in both their 
English and Italian versions. Table 2 shows some basic statistical data such as the number of words and the number of sentences in the two versions. Using the concordance software Sketch Engine (a corpus manager and text analysis software developed by Lexical Computing Limited since 2003) the corpus was trawled for the items in Hyland's 2005 list of metadiscourse features. The concordance lines were then manually searched in order to closely analyse every occurrence of the items under scrutiny. The purpose was to ensure that they were actually functioning as metadiscourse in that context, so that extraneous examples could be excluded from the count.

Table 2. Corpus of regulations on immigration (2016-2019)

\begin{tabular}{|c|c|c|c|c|c|c|}
\hline CORPUS & ENGLISH & ERSIONS & & ITALIAN & ERSIONS & \\
\hline REGULATIONS & TOKENS & WORDS & SENTENCES & TOKENS & WORDS & SENTENCES \\
\hline $\begin{array}{l}\text { REGULATION (EU) 2016/1191 of the European } \\
\text { Parliament and of the Council of } 6 \text { July } 2016 \text { on } \\
\text { promoting the free movement of citizens by simplifying } \\
\text { the requirements for presenting certain public documents } \\
\text { in the European Union }\end{array}$ & 11,917 & 9,729 & 232 & 11,780 & 9,684 & 230 \\
\hline $\begin{array}{l}\text { REGULATION (EU) 2018/1726 of the European } \\
\text { Parliament and of the Council of } 14 \text { November } 2018 \text { on } \\
\text { the European Union Agency for the Operational } \\
\text { Management of Large-Scale IT Systems in the Area of } \\
\text { Freedom, Security and Justice }\end{array}$ & 27,677 & 20,694 & 572 & 27,981 & 21,416 & 570 \\
\hline $\begin{array}{l}\text { REGULATION (EU) 2019/1240 of the European } \\
\text { Parliament and of the Council of } 20 \text { June } 2019 \text { on the } \\
\text { creation of a European network of immigration liaison } \\
\text { officers }\end{array}$ & 8,682 & 6,862 & 172 & 9,353 & 7,575 & 169 \\
\hline totals & 48,276 & 37,285 & 975 & 49,114 & 38,675 & 969 \\
\hline
\end{tabular}

It could be argued that the corpus used for the analysis is small: suffice it to say that these are the types of $a d$ hoc corpora used in class following Bhatia, Langton and Lung's (2004) suggestion concerning the application of corpus analysis within the context of legal language. The scholars state that small genre-based corpora are much more useful than large corpora because of certain linguistic peculiarities of legal language such as conservatism, crystallized formulae, and formulaic form-function correlations which make small legal corpora equally efficient and reliable. Of course, students are trained to understand that any claims and generalisations that can be made about language are representative of the language sample under investigation and research, not of the entire language (Biel, 2010, p. 2). The corpus will also be investigated using genre analysis (Bhatia, 1993; Swales, 1990) and through some fundamental tenets of Systemic Functional Linguistics (Halliday's in particular) in order to fulfil the quantitative-driven qualitativeness criteria for a thorough and all-embracing investigation.

\section{Metadiscourse: Interactive Features}

Following Hyland's classification (2005), the various metadiscoursal categories and their functions were the point of departure for the analysis of the data under scrutiny.

As for the interactive features, evidentials and frame markers were looked at as they are deemed to be as thoroughly and systematically representative of the regulation genre.

One of the most frequent structures in all three regulations in the English versions is the evidential in accordance with: Table 3 shows that this feature was found 23 times in Regulation 2016/1191 (REG2016 henceforth), 72 times in Regulation 2018/1726 (REG2018 henceforth) and 33 times in Regulation 2019/1240 (henceforth REG2019). 
Table 3. In accordance with and its translation into Italian

\begin{tabular}{|c|c|c|c|}
\hline \multicolumn{2}{|c|}{$\begin{array}{l}\text { EVIDENTIALS: } \\
\text { IN ACCORDANCE WITH ENGLISH VERSIONS }\end{array}$} & \multicolumn{2}{|c|}{ ITALIAN VERSIONS } \\
\hline \multirow[t]{7}{*}{ REGULATION (EU) 2016/1191 } & 23 & conformemente & 10 \\
\hline & & in base & 5 \\
\hline & & in conformità & 2 \\
\hline & & secondo & 2 \\
\hline & & a norma & 2 \\
\hline & & in ottemperanza & 1 \\
\hline & & alle condizioni & 1 \\
\hline \multirow[t]{7}{*}{ REGULATION (EU) 2018/1726 } & 72 & conformemente & 22 \\
\hline & & in conformità & 21 \\
\hline & & a norma & 12 \\
\hline & & secondo & 7 \\
\hline & & ai sensi & 6 \\
\hline & & in base & 2 \\
\hline & & in ottemperanza & 1 \\
\hline \multirow[t]{7}{*}{ REGULATION (EU) 2019/1240 } & 33 & conformemente & 11 \\
\hline & & in conformità & 10 \\
\hline & & ai sensi & 4 \\
\hline & & a norma & 4 \\
\hline & & secondo & 2 \\
\hline & & nel rispetto & 1 \\
\hline & & in ottemperanza & 1 \\
\hline Total & 128 & & \\
\hline
\end{tabular}

In accordance with is mainly used to refer to information from other texts which can be past regulations or Treaties, as is shown in the excerpts from the English versions below.

$(01 \mathrm{EN})$ The objective of Union policy in the field of migration is to replace irregular and uncontrolled migratory flows with safe and well-managed pathways, through a comprehensive approach aimed at ensuring, at all stages, the efficient management of migration flows in accordance with Chapter 2 of Title Vof the Treaty on the Functioning of the European Union (TFEU). [REG2019]

(02EN) This Regulation applies to public documents issued by the authorities of a Member State in accordance with its national law which have to be presented to the authorities of another Member State... [REG2016]

(03EN) The activities of the Agency should be subject to the scrutiny of the European Ombudsman in accordance with Article 228 TFEU. [REG2018]

Looking at the Italian versions of the examples given here, it can be noticed how the phrase in accordance with is rendered in several different ways such as conformemente, in conformità, in base, a norma, ai sensi, in ottemperanza meaning that the Italian language displays a larger lexico-grammatical variety when it comes to this legal expression. As underlined by Scarpa, "[...] the use of corpora in studies on translation allows us to analyze features of translation products which can illuminate the nature of the translation process (2006, p. 155).

(01IT) L'obiettivo della politica dell'Unione nel settore della migrazione è sostituire i flussi migratori irregolari incontrollati con percorsi sicuri e organizzati, mediante un approccio completo volto a garantire, in tutte le fasi, la gestione efficace dei flussi migratori conformemente al titolo V, capo 2, del trattato sul funzionamento dell'Unione europea (TFUE). [REG2019]

(02IT) Il presente regolamento si applica ai documenti pubblici rilasciati dalle autorità di uno Stato membro, in base alle propria legislazione nazionale, che devono essere presentati alle autorità di un altro Stato membro ... [REG2016]

(03IT) Le attività dell'Agenzia dovrebbero essere soggette al controllo del Mediatore europeo in conformità all'articolo 228 TFUE [REG2018].

Similarly, another evidential which shows a high frequency in the three texts in the English versions is pursuant to, another typical expression in legal English (Alcaraz \& Hughes, 2002, p. 166) as shown in Table 4: there are 6 
occurrences in [REG2016], 32 occurrences in [REG2018], 4 occurrences in [REG2019].

Table 4. Pursuant to and its translation into Italian

\begin{tabular}{llll}
\hline EVIDENTIALS: & \multicolumn{2}{l}{ ITALIAN VERSIONS } \\
PURSUANT TO ENGLISH VERSIONS & & & \\
\hline REGULATION (EU) 2016/1191 & 6 & a norma & 1 \\
& & ai sensi & 4 \\
& & di cui & 1 \\
REGULATION (EU) 2018/1726 & 32 & in conformità & 13 \\
& & ai sensi & 6 \\
& & conformemente & 5 \\
& & a norma & 3 \\
& & in base & 2 \\
& & in virtù & 1 \\
REGULATION (EU) 2019/1240 & 4 & other & 2 \\
& & a norma & 2 \\
total & 42 & ai sensi & 2 \\
\hline
\end{tabular}

Its use in the regulations under scrutiny is shown in the following examples, in both the English and the Italian versions of the EU instruments under analysis. When it comes to legal Italian, we can notice that this expression as well is rendered in various ways, such as a norma, ai sensi, in virtù, conformemente and in conformità.

(04EN) The Court of Justice of the European Union shall have jurisdiction to give judgment pursuant to any arbitration clause contained in a contract concluded by the Agency. [REG2018]

(04IT) La Corte di giustizia dell'Unione europea è competente a giudicare in virtù di clausole compromissorie contenute nel contratto concluso dall'Agenzia [REG2018]

(05EN) By 16 February 2018, the Commission shall publish the list of country-specific entry headings received pursuant to paragraph 2 in the Official Journal of the European Union and in the European e-Justice Portal in all official languages of the institutions of the Union [REG2016]

(05IT) Entro il 16 febbraio 2018 la Commissione pubblica gli elenchi delle voci specifiche per paese ricevute ai sensi del paragrafo 2 nella Gazzetta ufficiale dell'Unione europea e nel portale europeo della giustizia elettronica in tutte le lingue ufficiali delle istituzioni dell'Unione [REG2016]

(06EN) Where two or more Member States jointly deploy an immigration liaison officer, those Member States may receive Union financial support pursuant to Regulation (EU) No 515/2014. [REG2019]

(06IT) Se due o più Stati membri impiegano congiuntamente un funzionario di collegamento incaricato dell'immigrazione, tali Stati membri possono beneficiare di un sostegno finanziario dell'Unione a norma del regolamento (UE) n. 515/2014. [REG2019]

From the previous quantitative and qualitative analysis it can be inferred that a corpus-based investigation is particularly valuable since it helps to highlight the frequency and collocation of selected textual/linguistic elements and to gather information in terms of certain phraseology and discourse structures that are useful for translators (Pennisi, 2012, p. 34). Translators of specialized texts have to be able to recognize not only the most recurrent ST textual/linguistic elements, but also the textual/linguistic elements to be used in the TT.

As underlined earlier in this study, regulations have also been investigated for their most relevant generic features which make them unique in their distinctive style. In point of fact, professional and would-be translators should be aware of the lexico-grammatical peculiarities of each genre and subgenre. Genre analysis plays an important part since translation students get the opportunity to grasp and understand the rationale behind the texts and they can promptly achieve a certain awareness of the specialist discourse employed. For instance, by looking at the sequencing of the periods and parts of text or paragraphs in EU regulations, the observer can notice that frame markers are used to organize the linguistic material in the text. Frame markers belong to the category of interactive metadiscoursal devices devised by Hyland and comprise numbered or ordered lists which, contextually-wise, have the function of arranging and connecting the different parts of text in the EU instruments.

As shown by the excerpt below, the regulation usually starts with a long title: 
(07EN) REGULATION (EU) 2016/1191 OF THE EUROPEAN PARLIAMENT AND OF THE COUNCIL of 6 July 2016 on promoting the free movement of citizens by simplifying the requirements for presenting certain public documents in the European Union and amending Regulation (EU) No 1024/2012. [REG2016]

The text itself is preceded and introduced by a preamble, as shown in (08EN). The preamble "[...] is used to frame the main objective of the regulation and contextualize it within the EU legal space" (Molek-Kozakowska, 2014, p. 253). After that, the adverbial whereas introduces motivations and reasons before the main text.

(08EN) THE EUROPEAN PARLIAMENT AND THE COUNCIL OF THE EUROPEAN UNION,

Having regard to the Treaty on the Functioning of the European Union, and in particular Article 21(2) thereof,

Having regard to the proposal from the European Commission,

After transmission of the draft legislative act to the national parliaments,

Having regard to the opinion of the European Economic and Social Committee (1),

Acting in accordance with the ordinary legislative procedure (2),

Whereas:

[REG2016]

(08IT) IL PARLAMENTO EUROPEO E IL CONSIGLIO DELL'UNIONE EUROPEA,

visto il trattato sul funzionamento dell'Unione europea, in particolare l'articolo 21, paragrafo 2,

vista la proposta della Commissione europea,

previa trasmissione del progetto di atto legislativo ai parlamentari nazionali,

visto il parere del Comitato economico e sociale europeo (1)

deliberando secondo la procedura legislativa ordinaria (2),

considerando quanto segue:

[REG2016]

The Preamble refers to various other documents (such as the Treaty on the Functioning of the European Union), the European Commission's original proposal (as an executive document designed to realize EU' strategic aims), and the expert opinions used to draft the regulation, which in this case come from consultations with the European Economic and Social Committee. This regulation is issued after transmission of the draft to national parliaments and the adverbial whereas introduces several points that contain the main premises (explanations of motivations and reasons). In Italian, we find the phrase considerando quanto segue in lieu of the English whereas. In [REG2016], after a list of 57 premises, the performative act introduces the actual regulation with various chapter and articles.

(09EN) HAVE ADOPTED THIS REGULATION

CHAPTER 1

SUBJECT MATTER, SCOPE AND DEFINITIONS

Article 1

Subject matter

1) This Regulation provides...

Subsequently, chapters and articles follow through the use of frame markers such as numbered or ordered lists, covering substantive provisions, definitions, rights and obligations. Article 2 Scope, and Article 3 Definitions are included in CHAPTER 1. Then, 4 other chapters follow until the readers get to the last chapter, CHAPTER VI GENERAL AND FINAL PROVISIONS. The final clauses or final dispositions can contain information about the central authorities and contact details, an exchange of best practices, information to be communicated by Member States, amendments, and, finally the date of coming into force in Article 27:

(10EN) Article 27

Entry into force

1) This Regulation shall enter into force on the twentieth day following that of its publication in the Official 
Journal of the European Union.

2) It shall apply from 16 February $2019, \ldots$

[...]

This Regulation shall be binding in its entirety and directly applicable in all Member States.

Done at Strasbourg, 6 July 2016

This last Article presents the entry into force of the regulation, after which Annexes can follow. The Italian version of the Regulation has the same structure, with the same ordered and numbered lists till Articolo 27, which closes the Regulation with the entrata in vigore.

Therefore, the examples given here of the use of evidentials and frame markers in the English and Italian versions show that employing the quantitative-driven qualitativeness methodology makes translation students able to observe the specific discoursal moves and linguistic devices that are typical of the specific genre of EU regulations.

\section{Metadiscourse: Interactional Features}

Simultaneously with its organization as a message from the textual point of view, a clause is also organized as an interactive event involving the writer (or speaker) and the audience. In the clause as exchange, the 'content' (or function) of the text is conveyed through the act of speaking, that is that the writer (or speaker) adopts for himself/herself a particular speech role and in so doing assigns a complementary role to the reader. Since we are dealing with regulations, and WHAT THEY SAY IS LAW, they primarily have to do with the speech function that Halliday and Matthiessen (2004) define as command: this aspect will be fundamental in the investigation of the metadiscoursal devices of interactional character which concern the building of a relationship between writer and reader. Among the devices which involve the readers in the text, the intent is to focus on attitude markers (adjectives, in a specific way) and hedges (modal verbs, should and shall).

Attitude markers convey the writer's affective and emotional attitudes, expressing an explicit positive or negative value "that is gradable (important/very important) to propositions" (Hyland, 2005, p. 149). Attitude markers are most explicitly signaled by attitude verbs, adverbials, adjectives and nouns. For the purpose of this study, only attitude adjectives are taken into account.

It is important to point out that this research does not take into account determinative adjectives, i.e., deictics, numerals and classifiers, as they are defining adjectives and convey an experiential metafunction in the clause. In the following example, illegal is for instance a case of determinative adjective:

(11EN) illegal immigration [REG2019]

in which the adjective is a Classifier and therefore has a defining function within the nominal group. Accordingly, this study takes into consideration only Epithet (Halliday, 1985), since it does not indicate an objective property of the Thing itself, but some quality of the Thing, expressing in so doing the writer's subjective attitude towards it, thus representing an interpersonal element in the meaning of the nominal group (cfr. Halliday \& Matthiessen, 2004). The line between Epithet and Classifier is not a particularly marked one, but it is possible to recognize some significant differences. Classifiers from a semantic point of view do not accept degrees of comparison or intensity- for instance, we cannot have a more illegal immigration, or a very illegal immigration (unless it is for rhetorical and hyperbolic reasons), but Classifiers tend to be organized in mutually exclusive, discrete and exhaustive sets: i.e., immigration is either legal or illegal.

In the corpus under scrutiny, interpersonal Epithets are present in both the form of 1) positive Adjectives of the attributive type, such as in (12EN) appropriate safeguards [REG2019] and 2) of the Predicative type, as in example (13EN) It should therefore be possible for immigration liaison officers [...] [REG2019].

As stated above, a crucial feature of Epithets in contrast to Classifiers is that the former are semantically gradable, i.e., not being extreme or absolute in nature, they describe qualities that can be measured or graded in some way. In the following example, the positive adjective good has been intensified by the use of a comparative, both in English and in Italian:

(14EN) better coordination and cooperation among all liaison officers [REG2019]

(14IT) migliore coordinamento e una migliore cooperazione tra tutti i funzionari di collegamento [REG2019]

In addition, expressions of attitude tend also to be prosodically tied throughout the clause in the sense that Epithets tend to be reinforced by other Epithets forming accumulations that create rhetorical figures all 
contributing to the same meaning-function. By adding synonyms, intensifiers and the like, the aim is that of ideally doubling the interactional meaning-function of the metadiscourse. In the following example, notice the alliteration which enhances the prosody of the cluster.

(15EN) dignified and effective return, readmission and reintegration activities [REG2019]

(15IT) attività di rimpatrio, riammissione e reintegrazione efficaci e dignitose [REG2019]

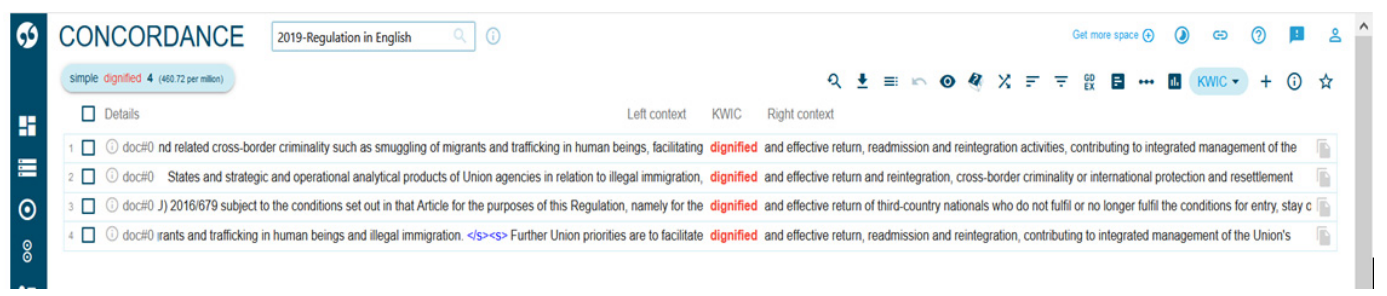

Figure 2. Concordances for the adjective dignified

The next interactional feature analysed regards hedges, and in particular the modal verbs should and shall. Hedges are devices which indicate the author's decision to recognize and admit in some way that there may be potential alternative viewpoints and voices and thus "withhold complete commitment to a proposition" (Hyland, 2005 , p. 52). Hedges highlight subjectivity of a position by allowing information to be presented as an opinion rather that an objective fact and, therefore, open that position to negotiation.

Table 5 below shows the occurrences of shall and should in the three regulations:

Table 5. Occurrences of shall and should in the English corpus

\begin{tabular}{llll}
\hline Modals & {$[$ REG2016] } & [REG2018] & [REG2019] \\
\hline shall & 65 & 292 & 59 \\
should & 103 & 114 & 39 \\
\hline
\end{tabular}

As noted above, what is stated in a Regulation becomes law. So looking at the sentence from the interactional layer of meaning, the function of the positive and negative poles is "prescribing and proscribing: positive imperative 'do it', negative imperative 'don't do it'" (Halliday \& Matthiessen, 2004, p. 147). Therefore, polarity is to be expected in a regulation. However, occurrences show the presence of devices in a semantic space conveying intermediate possibilities. These different scales of obligations are defined as "modulation" (Halliday \& Matthiessen, 2004, p. 147); modal auxiliaries, whether deontic or epistemic, can be interpreted as hedges whenever they express a certain degree of vagueness (Hyland, 2005).

Given the general tendency of lawmakers to avoid ambiguity and subjective interpretation, preventing grey areas where possible, the role of should in prescriptive legal texts, in which 'what they say is law', is expected to be fairly circumscribed and contained (cfr. Williams, 2005). As can be seen in the examples below, the deontic strength of the modal should occurs pervasively in all three EU Regulations under scrutiny.

In (16EN) there is no explicit obligation to involve authorities of EU Member States further with the 'transmission of information'; merely that greater involvement would be the best idea.

(16EN) Any exchange or transmission of information and documents by the authorities of the Member States should be in accordance with Directives 95/46/EC. [REG2016]

In some cases, should occurs with some adverbial hedges (where possible and relevant), thereby enhancing fuzziness, and thus producing vagueness, indeterminacy and limiting to a certain extent its objective relevance.

(17EN) Information on the composition of migratory flows should, where possible and relevant, include information on declared migrants' age, gender profile and family and on unaccompanied minors. [REG 2019].

However, in some cases should would seem to be the most appropriate and pertinent form to be used in EU Regulations, for instance when propounding general principles and guidelines which often have powerful, ethical and/or moral overtones and implications. This happens especially when dealing with priorities and emergency 
needs concerning the human aspects of immigration policy:

(18EN) A Steering Board should provide guidance in line with Union policy priorities [...] and should be given the necessary powers... [REG2019]

(18IT) Un comitato direttivo dovrebbe fornire orientamenti in linea con le priorità strategiche dell'Unione [...] e dovrebbe inoltre essere dotato dei poteri necessari... [REG2019]

In example (19EN), it cannot be said that an obligation is laid down when affirming that Europol should have observer status [...], but the modal should is merely stating how things should or ought to be, not how they must be. Otherwise stated, it can be affirmed that there is a sort of "behaviour regulation" (Williams, 2005, p. 131) in the sentence, although it does not convey the full force of an unambiguous illocutionary force of an obligation.

(19EN) As regards ETIAS, Europol should have observer status at the meetings of the Management Board when a question concerning Regulation (EU) 2018/1240 is on the agenda. [REG2018]

When the modal should occurs in main clauses, it has been translated into Italian in two different ways, according to its different syntactical construction:

1) with the mood of condizionale in the present tense (dovrebbe), as in examples (18IT) in which the modal verb dovrebbe governs the infinitive form of the main verb that follows (dovrebbe fornire);

2) or, as an alternative, when the conditional form of the modal verb governs the two auxiliaries be or have the translation has been rendered with the predicate adjective $\dot{e}$ opportuno, stressing convenience and appropriateness, as in examples (21EN) and (21IT):

(20EN) Building on this experience, [...] deployments of immigration liaison officers by the Commission [...] should be foreseen to support development... [REG2019]

(20IT) Sulla base di questa esperienza, è opportuno prevedere che la commissione invii funzionari di collegamento incaricati dell'immigrazione... [REG2019]

It is worth observing that so far the modal should has been analyzed only in main sentences, but in the Regulations under scrutiny should can also be found in the protasis of a conditional clause, namely in a construction which is typically of formal English "with a zero-conjunction and inversion, provided that the verb of the conditional clause is a modal form" (Declerck, 1991, p. 425).

(21EN) Due to the specific nature of the systems, should it become necessary for the Agency to establish a second separate technical site either in Strasbourg [...] [REG2018]

(21IT) In ragione della natura specifica dei sistemi, qualora dovesse rendersi necessario per l'Agenzia istituire un secondo sito tecnico distinto a Strasburgo [...] [REG2018]

When should occurs as a protasis in hypothetical subordinate clauses, as in (21EN), it has been rendered with the modal dovere in the imperfect subjunctive governing the main verb in the pronominal form 'rendersi' (qualora dovesse rendersi necessario).

Apart from the cases in which should occurs in the protasis of hypothetical clauses, in which it conveys epistemic rather than deontic modality, in the first two examples when should occurs in the main clauses, the meaning is not assertive but rather corroboration-seeking. By rounding off and smoothing the illocutionary force of the peremptoriness of the Regulation, should signals vagueness and thus confirms the 'medium strength' and the 'freedom of action'. Modality acts like hedging, emphasizing the weak, tentative nature used not for command but for advisable action in cooperative speech. Although the general tendency of lawmakers is that of avoiding ambiguity where possible, the role of should in prescriptive Regulations is rather remarkable, as already seen from the quantitative analysis carried out in this study.

Together with the occurrences of items expressing "modulation" (Halliday \& Matthiessen, 2004, p. 147), namely showing the presence of devices in a semantic space conveying intermediate possibilities, the presence of polarity ('do it' or don't do it') in EU Regulations is however notable. As well as having gradually acquired an ever more archaic quality which endows it with the authoritativeness of tradition, the development of shall in legal discourse has grown from the need to avoid ambiguity and normally to convey an unmistakably prescriptive dimension to verbal constructions (Barber, 1994; Williams, 2005). According to Rissanen (2000), the use of shall in prescriptive legal texts conveys a connotation of obligation, which is immanently and intrinsically projected towards ruling and regulating situations and behaviour situated in the present and future (cfr. Williams, 2005). In addition, with its increasing tendency towards a sense of depersonalization, or "impersonalization" - as stated by Šarčevič (2000, p. 176) - , shall is "well-suited for use in a type of discourse 
[...] to avoid any kind of personal references, eschewing almost entirely the first and second persons $[\ldots]$ in favour of the more neutral third person" (Williams, 2005, p. 116). As can be seen from the examples below (22EN and 23EN), its core function appears to be that of expressing authoritativeness and command by imposing certain forms of prescription and proscription (cfr. Palmer, 1990; Williams, 2005), conveyed by explicitly identifying the agentive person(s), or body, or State(s) that is bound to carry out the obligation:

(22EN) Immigration liaison officers shall carry out their tasks within the framework of their responsibilities determined by the deploying authorities and in accordance with the provisions [...] [REG2019]

(22IT) I funzionari di collegamento incaricati dell'immigrazione assolvono i loro compiti nel'ambito delle loro responsabilità stabilite dalle autorità che procedono all'impiego e conformemente alle disposizioni [...] [REG2019]

(23EN) Given that this Regulation [...] builds upon the Schengen acquis, Denmark shall, in accordance with Article 4 of that Protocol, decide within a period of six months after the Council has decided on this Regulation whether it will implement it in its national law. [REG2019]

(23IT) Dato che il presente regolamento [...] si basa sull'acquis di Schengen, la Danimarca decide, ai sensi dell'articolo 4 di tale protocollo, entro sei mesi dalla decisione del Consiglio sul presente regolamento, se intende recepirlo nel proprio diritto interno. [REG2019]

However, on certain circumstances, the sense of obligation is a generic one and often expressed using thematized grammatical subjects in the passive form and not involving any particular agentive role:

(24EN) Information collected under this paragraph shall be collected in accordance with Article 1(2) [Reg2019]

(24IT) Le informazioni raccolte ai sensi del presente paragrafo sono raccolte in conformità dell'articolo 1 , paragrafo 2 [...] [REG2019]

The question arises as to the exact translation to be assigned to the modal shall in the Italian versions of EU Regulations. The concentration of cases of the indicativo presente to render the modal shall in all the Italian versions should not really surprise because "in Romance languages such as Italian the present simple is used". Indeed, it is a general feature in many European countries that the language of the law is written predominantly in the same tense as it is also the one most widely employed in everyday communication: "there is nothing [...] particularly projected towards the future or overtly modal in the way that shall has become in English" (Williams, 2005, pp. 152-153). Accordingly, it is possible to say that the Italian indicativo presente in Regulations and in general in all prescriptive legal texts in Italian takes the illocutionary force of a "normative indicative" (Williams, 2005, p. 154) having essentially the same degree of authoritativeness as the English shall and thus conveying deontic modality.

\section{Conclusions}

This study has presented an example of how ad hoc parallel corpora can be used in the context of translation masters courses in order to train students both academically and professionally. This didactic approach, both educational and professional, can adequately prepare future translators for multilingual environments and professional contexts such as the EU institutions. Taking into account the fact that the drafting and translation processes in these contexts are not carried out individually but collectively (and thus the translators often remain anonymous and relatively invisible) it seems constructive to carry out this type of training exploiting pair work and group work so that the professional collective environment is recreated in the classroom context. Smaller, carefully constructed sample corpora can be analysed/investigated exhaustively in a variety of ways and with a vast array of didactic strategies.

As with interactive metadiscursive resources (i.e., evidentials and frame markers) translation students acquire competence and awareness of the structures underlying source texts and their translations, so with the in-depth analysis of interactional features (such as attitude markers and hedges) would-be translators explore the specific field and the specialized discourse thoroughly and methodically. A systematic and meticulous exploration (both quantitative and qualitative) of the linguistic aspects in parallel texts enables students and trainees to understand and recognize the translation choices adopted by professional translators in their professional practice for EU or international institutions.

As Pearson has said, parallel corpora play an important role in translator training environment, and students can use parallel corpora to help them with translation; they can see how professional translators have overcome specific translation problems. In point of fact, the findings from corpus-based studies of parallel corpora (and the 
linguistic analysis, the authors would add) can and should inform the design and the implementation of specialized translation courses (Pearson, 2014).

Indeed, the future of multilingualism in EU laws and Regulations depends on the ability of professional translators to produce reliable texts. In view of the significance that parallel texts produced in EU Institutions are equally authentic makes it essential for professional translators to guarantee the reliability of authenticated translations. Since reliability can be secured only if there is greater professionalism in the field of legal translation, the classroom experiences in Cagliari University Translation Masters' courses have responded by organizing classes and graduate programs which provide interdisciplinary training in Genre Analysis, Systemic Functional Linguistics and translation. The exclusive emphasis on terminological aspects and the unique mastering of technical terminology both of the source and the target legal system is insufficient to make a potential translator competent. To develop translation competence, students in Translation courses also need instructions in theory, and, as this study has attempted to show, a theory of translation must be practice oriented in order to be effective. Legal translation should be regarded as an act of communication in mechanism of law (Šarčević, 2000). To this end, it is crucial to provide concrete criteria to assist students Translation courses to evaluate the pragmatic and functional aspects of various communicative situations. Since it is the function that counts in legal communication, perfect communication can be said to occur when the parallel texts of a single piece of legislation are interpreted and applied uniformely as indicated by the legislator, States parties, or contracting parties (cfr. Šarčević, 2000).

\section{Acknowledgements}

Though this paper has been jointly conceived, organised and developed, Michela Giordano is responsible for Sections 1, 3, and 4, while Antonio Piga is responsible for sections 2, 5, and 6. The general plan and editing was a cooperative, shared effort.

\section{References}

Al Fajri, M. S. (2017). Hegemonic and minority discourses around immigrants: A corpus-based critical discourse analysis. Indonesian Journal of Applied Linguistics, 7(2), 381-390. https://doi.org/10.17509/ijal.v7i2.8349

Alcaraz, E., \& Hughes, B. (2002). Legal Translation Explained. Manchester: St. Jerome Publishing.

Baker, P., \& McEnery, T. (2005). A Corpus-based Approach to Discourses of Refugees and Asylum Seekers in UN and Newspapers Texts. Journal of Language and Politics, 4(2), 197-226. https://doi.org/10.1075/jlp.4.2.04bak

Barber, C. (1994). The English Language: A Historical Introduction. Cambridge: Cambridge University Press.

Bernardini, S., \& Castagnoli, S. (2008). Corpora for translator education and translation practice. In E. Y. Rodrigo (Ed.), Topics in Language Resources for Translation and Localisation (pp. 39-55). Amsterdam, The Netherlands: John Benjamins Publishing Company. https://doi.org/10.1075/btl.79.04ber

Bhatia, V. K. (1993). Analysing Genre: Language Use in Professional Settings. London: Longman.

Bhatia, V. K., Langton, N. M., \& Lung, J. (2004). Legal discourse: Opportunities and threats for corpus linguistics. In C. Ulla \& A. U. Thomas (Eds.), Discourse in the professions: Perspectives from Corpus Linguistics (pp. 203-231). Amsterdam: John Benjamins. https://doi.org/10.1075/scl.16.09bha

Biel, Ł. (2010). Corpus-based Studies of Legal Language for Translation Purposes: Methodological and Practical Potential. In H. Carmen \& E. Jan (Eds.), Reconceptualizing LSP (pp. 1-15). Online Proceedings of the XII European LSP Symposium 2009, Aarhus: Aarhus School of Business, Aarhus University.

Borchardt, K. D. (2018). The ABC of EU law. Directorate-General for Communication (European Commission), Publications Office of the EU.

Declerck, R. (1991). Tense in English: Its Structure and Use in Discourse. London: Routledge.

Felici, A. (2010). Translating EU law: Legal issues and multiple dynamics. Perspectives: Studies in Translatology, 18(2), 95-108. https://doi.org/10.1080/09076761003668289

Gibová, K. B. (2009). EU Translation as the Language of a Reunited Europe Reconsidered. In Language, Literature and Culture in a Changing Transatlantic World (pp. 145-153, 192-202). International Conference Proceedings. Prešov: Prešov University.

Giordano, M., \& Piga, A. (2020). Beyond the Boundaries: Migration Discourse in EU Parliamentary Debates. Lingue e Linguaggi- ISSN: 2239-0367, Vol. 39, 131-156. 
Grego, K., \& Vicentini, A. (2015). European Migration English: Naming People on the Move. Textus. English Studies in Italy, 28(2), 63-84.

Halliday, M. A. K. (1985). An Introduction to Functional Grammar. London: Arnold.

Halliday M. A. K., \& Matthiessen, C. M. I. M. (2004). An Introduction to Functional Grammar. London: Arnold.

Hyland, K. (2019, 2005). Metadiscourse. Exploring Interaction in Writing. London-New York: Continuum.

Koskinen, K. (2000). Institutional Illusions. Translating in the EU Commission. The Translator, 6(1), 49-65. https://doi.org/10.1080/13556509.2000.10799055

Koskinen, K. (2001). How to research EU translation? Perspectives: Studies in Translatology, 9(4), 293-300. https://doi.org/10.1080/0907676X.2001.9961425

Manca, E. (2015). Un approccio corpus-driven al linguaggio dell'immigrazione. Lingue e Linguaggi, 16, $485-507$.

Martin, J. R. (1991). Intrinsic Functionality: implications for contextual theory. Social Semiotics, 1(1), 99-162. https://doi.org/10.1080/10350339109360331

Molek-Kozakowska, K. (2014). The style of EU directives and the discourse of expert rationality. Stylistyka, 23, 245-261.

Palmer, F. R. (1990). Modality and the English Modals. London: Longman.

Pearson, J. (2014). Using Parallel Texts in the Translator Training Environment. In Z. Federico, B. Silvia \& S. Dominic (Eds.), Corpora in Translator Education. Manchester, UK: St. Jerome Publishing.

Pennisi, G. A. (2012). Translating Legal Texts. When Language Meets Law. Torino: G. Giappichelli Editore.

Rissanen, M. (2000). Standardization and the Language of Early Statutes. In W. Laura (Ed.), The Development of Standard 1300-1800 (pp. 117-130). Cambridge: Cambridge University Press. https://doi.org/10.1017/CBO9780511551758.008

Šarčević, S. (2000). New Approach to Legal Translation. The Hague: Kluwer Law International.

Scarpa, F. (2006). Corpus-based Quality Assessment of Specialist Translation: A Study Using Parallel and Comparable Corpora in English and Italian. In G. Maurizio \& Š. Susan (Eds.), Insights into Specialised Translation (pp. 155-172). Bern: Peter Lang.

Swales, J. M. (1990). Genre Analysis. English in Academic and Research Settings. Cambridge: Cambridge University Press.

Wagner, E., Bech, S., \& Martínez, J. M. (2012). Translating for the European Institutions. Manchester: St. Jerome Publishing.

Williams, C. (2005). Tradition and Change in Legal English. Bern: Peter Lang. https://doi.org/10.3726/978-3-0351-0317-5

\section{Webliography}

https://eur-lex.europa.eu/homepage.html, last accessed January 2021.

https://op.europa.eu/en/publication-detail/, last accessed January 2021.

\section{Copyrights}

Copyright for this article is retained by the author, with first publication rights granted to the journal.

This is an open-access article distributed under the terms and conditions of the Creative Commons Attribution license (http://creativecommons.org/licenses/by/4.0/). 